\title{
The effect of copper level in the diet on the distribution, and biological and immunological responses in a rat model
}

\author{
E. Cholewińska ${ }^{1,3}$, B. Fotschki ${ }^{2}$, J. Juśkiewicz ${ }^{2}$, E. Rusinek-Prystupa ${ }^{1}$ and K. Ognik ${ }^{1}$ \\ ${ }^{1}$ University of Life Science in Lublin, Faculty of Biology, Animal Sciences and Bioeconomy, \\ Department of Biochemistry and Toxicology, Akademicka 13, 20-950 Lublin, Poland \\ ${ }^{2}$ Institute of Animal Reproduction and Food Research of the Polish Academy of Sciences, Division of Food Science, \\ Tuwima 10, 10-748 Olsztyn, Poland
}

KEY WORDS: copper carbonate, distribution, immunity, tissues, rats

Received: $\quad 6$ March 2018

Revised: $\quad 29$ May 2018

Accepted: 12 December 2018
${ }^{3}$ Corresponding author:

e-mail: ewelina.cholewinska@mailplus.pl
ABSTRACT. The aim of the study was to evaluate the effect of copper (Cu) level in the diet on the distribution, and biological and immunological responses in a rat model. Two experimental groups of rats received a diet containing the recommended (higher) amount $(6.5 \mathrm{mg} / \mathrm{kg})$ of $\mathrm{CuCO}_{3}(\mathrm{CuH})$ or a diet containing the reduced (lower) level of $\mathrm{Cu}$ (without $\mathrm{CuCO}_{3}$ supplementation; $\mathrm{CuL}$ ) for 7 or 35 days (T7 and T35, respectively; in total 4 subgroups). Reduced level of Cu caused a decrease in the $\mathrm{Cu}$ excretion in faeces and an increase in the $\mathrm{Cu}$ level in urine, but in overall the digestibility and utilization indexes of Cu were increased. There was also found a decrease in the Cu content in the plasma and liver in CuL group (results of a 5-day balance tests). After 7 days the reduction of $\mathrm{Cu}$ dose caused a decrease in plasma contents of $\mathrm{Cu}, \mathrm{Zn}, \mathrm{Fe}, \mathrm{Ml}(\%), \mathrm{GRA}$ $\left(10^{\circ} /\right)$, IgA and IgM; on the other hand the plasma contents of Mg, WBC, LYM (\%) and BIL, and activities of ALP and GGT were increased. The elongation of the feeding period from 7 to 35 days in the $\mathrm{CuH}$ group caused a decrease of $\mathrm{Zn}, \mathrm{P}, \mathrm{IgA}, \mathrm{BIL}, \mathrm{TC}, \mathrm{TG}$ plasma contents, and activity of ALT, LDH and an increase in WBC, LYM (\%), MID (10\%/l), MI (\%), GRA (\%), RBC, HB, IgM, IL-6, GLU, UA, ALB and HDL and activities of AST, ALP and GGT. However when the CuL diet was elongated, decreased plasma contents of $\mathrm{Cu}, \lg A, \lg M, I L-6$, GLU, ALB and BIL, and activity of GGT; and increased plasma contents of Zn, WBC, LYM (\%) and GRA (10\%), and activity of ALP were stated in comparison to $\mathrm{CuH}$ group. The results of the study suggest that rats partially develop adaptive mechanisms, thanks to which are able to function at a reduced level of $\mathrm{Cu}$ in the diet. But, reduced level of $\mathrm{Cu}$ in the diet may interfere with the immune response and BIL and ALB metabolisms, playing an antioxidant role in the body. Furthermore, it can be indicated that the level of many blood indicators may depend on the growth of rats, therefore it may not be assumed that the supplementation of $\mathrm{Cu}$ in rats is completely unnecessary.

\section{Introduction}

Copper $(\mathrm{Cu})$ is an important nutrient determining the proper development and functioning of the body (Al-Naimi et al., 2010; Majewski et al., 2017).
This microelement stabilizes cell membrane permeability by taking part in oxidation of membrane thiol compounds to disulphides (Kim et al., 2008). It is also a component of numerous enzymes responsible for energy metabolism (e.g., cytochrome c oxidase, 
lysyl and ascorbate oxidase) and antioxidant defence of the body (e.g., superoxide dismutase) (Gaetke and Chow, 2003; Ognik et al., 2016; Cholewińska et al., 2018a). Importantly, $\mathrm{Cu}$ is responsible for iron metabolism and its incorporation into haemoglobin molecules, ensuring the proper level of oxygenation of the body. $\mathrm{Cu}$ also has an important role in the synthesis of elastin, collagen and melanin, which protects the body against ageing (Collins et al., 2010). The presence of $\mathrm{Cu}$ in the body, through its participation in the synthesis and denaturation of neurotransmitters, also helps to maintain the integrity of the central nervous system (Opazo et al., 2014). By contributing to the transformation of arachidonic acid and synthesis of prostaglandins, $\mathrm{Cu}$ reduces the severity of inflammatory processes in the body (Ognik et al., 2016).

Most of the available research results suggest that $\mathrm{Cu}$ is an element that should be supplemented into the diet. Otherwise, its deficit in the body may result in serious metabolic and functional disorders (Huang and Failla, 2000; Harless et al., 2006; Pyatskowit and Prohaska, 2008; Smith et al., 2008; Ozkul et al., 2011; Matak et al., 2013; Wazir and Ghobrial, 2017; Cholewińska et al., 2018b). Symptoms of Cu deficiency in the body include anaemia, neutropenia, growth and reproduction disorders, bone damage, heart failure and gastrointestinal disorders (Aoki, 2004). Hypercholesterolemia, hypertension and glucose intolerance may also occur (Song et al., 2012). In young, developing individuals, $\mathrm{Cu}$ deficiency may result in hypotonia, psychomotor delay and hypothermia (Aoki, 2004). Acquired Cu deficiency is also associated with a number of serious neurological changes, such as myelopathy, isolated peripheral neuropathy, cerebral demyelination or optic neuropathy (Jaiser and Winston, 2010). Failure to satisfy the body's need for $\mathrm{Cu}$ may also cause vision disorders due to demyelination or dysmyelination of the optic nerves (Dake and Amemiya, 1991). There is some probability that $\mathrm{Cu}$ deficiency may be directly linked to the incidence of Alzheimer's disease, which etiopathogenesis is not yet fully understood; the content of this microelement has been found to be significantly lower in biological material collected from Alzheimer's disease patients as compared to individuals with confirmed dementia or other neurological diseases (Deibel et al., 1996; Klevay, 2008).

In recent years there were few studies showing that the lack of supplementation of $\mathrm{Cu}$ in the diet is not as harmful as previously assumed. The organism can adapt perfectly to these seemingly unfavourable eating conditions (Seol et al., 2015; Shukla et al., 2015). Therefore, the aim of our study was to assess the effect of a $\mathrm{Cu}$ deficiency in the diet on the absorption and biodistribution of this element and on haematological, immune and biochemical parameters in rats.

\section{Material and methods}

\section{Animal protocol and dietary treatments}

All animal care and experimental protocols were in compliance with current laws governing animal experimentation in the Republic of Poland and with guidelines established by an ethics committee, in accordance with the European Convention for the Protection of Vertebrate Animals used for Experimental and other Scientific Purposes, Directive 2010/63/EU for animal experiments, and were approved by the appropriate Local Institutional Animal Care and Use Committee.

Thirty-two healthy male albino Wistar rats $\{$ (Han IGS Rat $[\mathrm{Crl}: \mathrm{WI}(\mathrm{Han})]\}$ aging 5 weeks with an average body weight of $135 \pm 10 \mathrm{~g}$ were randomly divided into 2 groups. The rats were housed aimlessly and individually in stainless steel cages at a stable temperature $\left(21-22^{\circ} \mathrm{C}\right)$, relative humidity $50 \pm 10 \%$, a 12-h light-dark cycle, and a ventilation rate of 20 air changes per hour. For 7 or 35 days $(\mathrm{CuH}-7-8$ animals, CuH-35 -8 animals, CuL-7 -8 animals, CuL$35-8$ animals, respectively), the rats had free access to tap water and semi-purified diets, which were prepared and then stored at $4{ }^{\circ} \mathrm{C}$ in hermetic containers until the end of the experiment (Table 1). The diets were modifications of a casein diet for laboratory rodents (AIN-93G) recommended by the American Institute of Nutrition (Reeves, 1997). In the study, two experimental treatments were used to evaluate the effects of the $\mathrm{CuCO}_{3}$ presence or absence in the diet.

The rats were divided into following groups: $\mathrm{CuH}$ group - the rats were fed a diet with a standard mineral mixture (MX) resulting in $6.5 \mathrm{mg} \mathrm{Cu}$ (from $\mathrm{CuCO}_{3}$ in $\mathrm{MX}$ ) per kg of diet; and $\mathrm{CuL}$ group - the rats were fed a diet with a MX without $\mathrm{Cu}$ supplementation $\left(\mathrm{CuCO}_{3}\right.$ excluded from $\left.\mathrm{MX}\right)$. The rats in each group $(\mathrm{CuL}$ or $\mathrm{CuH} ; 16$ rats in each) received their respective diet for 7 or 35 days - T7 or T35, respectively ( 8 rats from each group; in total 4 subgroups) (Table 2). The detailed composition of the mineral mixtures used in the experimental groups is given in Table 3.

All physiological measurements were made separately for each animal ( $\mathrm{n}=8$ for each subgroup). During the study, $\mathrm{Cu}$ digestibility and utilization tests (balance tests) were carried out. After a 10-day preliminary period, the faeces and urine were col- 
Table 1. Composition of basal diet fed to rats, $\%$

\begin{tabular}{|c|c|}
\hline Indices & Content \\
\hline \multicolumn{2}{|l|}{ Invariable ingredients } \\
\hline casein $^{1}$ & 14.8 \\
\hline DL-methionine & 0.2 \\
\hline cellulose ${ }^{2}$ & 8.0 \\
\hline choline chloride & 0.2 \\
\hline rapeseed oil & 8.0 \\
\hline cholesterol & 0.3 \\
\hline vitamin mixture ${ }^{3}$ & 1.0 \\
\hline maize starch ${ }^{4}$ & 64.0 \\
\hline \multicolumn{2}{|l|}{ Variable ingredient } \\
\hline mineral mixture ${ }^{5}$ & 3.5 \\
\hline \multicolumn{2}{|l|}{ Calculated content } \\
\hline crude protein & 13.5 \\
\hline \multicolumn{2}{|c|}{$\begin{array}{l}{ }^{1} \text { casein preparation: crude protein } 89.7 \% \text {, crude fat } 0.3 \% \text {, ash } 2.0 \% \text {, } \\
\text { and water } 8.0 \% ;{ }^{2} \text { a-cellulose (Sigma-Aldrich, St. Louis, MO, USA), } \\
\text { main source of dietary fibre; }{ }^{3} \mathrm{AIN}-93 \mathrm{G}-\mathrm{VM} \text {, g per kg of mixture: nicotin- } \\
\text { ic acid } 3.0, \mathrm{Ca} \text {-pantothenate } 1.6 \text {, pyridoxine-HCI } 0.7 \text {, thiamine-HCI } 0.6 \text {, } \\
\text { riboflavin } 0.6 \text {, folic acid } 0.2 \text {, biotin } 0.02 \text {, vit. } \mathrm{B}_{12} \text { (cyanocobalamin, } 0.1 \% \\
\text { in mannitol) } 2.5 \text {, vit. E (all-rac-a-tocopheryl acetate, } 500 \mathrm{IU} / \mathrm{g}) 15 \text {, } \\
\text { vit. A (all-trans-retinyl palmitate, } 500000 \mathrm{IU} / \mathrm{g} \text { ) } 0.8 \text {, vit. } \mathrm{D}_{3} \text { (cholecalcif- } \\
\text { erol, } 400000 \mathrm{IU} / \mathrm{g} \text { ) } 0.25 \text {, vit. } \mathrm{K}_{1} \text { (phylloquinone) } 0.075 \text {, powdered su- } \\
\text { crose } 974.655 ;{ }^{4} \text { maize starch preparation } \%: \text { crude protein } 0.6 \text {, crude } \\
\text { fat } 0.9 \text {, ash } 0.2 \text {, total dietary fibre } 0 \text {, water } 8.8 ;{ }^{5} \text { mineral mixture with or } \\
\text { without } \mathrm{Cu} \text {, see Tables } 2 \text { and } 3\end{array}$} \\
\hline
\end{tabular}

Table 2. Experimental design (copper dosage calculated from $\mathrm{CuCO}_{3}$ in mineral mixture $(M X)$ )

\begin{tabular}{lll}
\hline $\begin{array}{l}\text { Feeding } \\
\text { period }(\mathrm{T})\end{array}$ & $\begin{array}{l}\text { Treatment } \\
(\mathrm{CuH}\end{array}$ & $\begin{array}{l}\mathrm{CuL} \\
(\mathrm{n}=16)\end{array}$ \\
\hline 7 & $\begin{array}{l}\text { diet containing } 6.5 \mathrm{mg} / \mathrm{kg} \mathrm{Cu} \\
\text { from } \mathrm{CuCO}_{3}(\mathrm{n}=8)\end{array}$ & $\begin{array}{l}\text { diet with } \mathrm{MX} \text { without } \mathrm{CuCO}_{3} \\
\text { addition }(\mathrm{n}=8)\end{array}$ \\
35 & $\begin{array}{l}\text { diet containing } 6.5 \mathrm{mg} / \mathrm{kg} \mathrm{Cu} \\
\text { from } \mathrm{CuCO}_{3}(\mathrm{n}=8)\end{array}$ & $\begin{array}{l}\text { diet with } \mathrm{MX} \text { without } \mathrm{CuCO}_{3} \\
\text { addition }(\mathrm{n}=8)\end{array}$ \\
\hline
\end{tabular}

$n=8$, number of rats used in each feeding period in each experimental group; $n=16$, number of rats used in each experimental group

lected for 5 days from all rats, which were kept in balance cages (Tecniplast S.p.A, Buguggiate, Italy). The content of $\mathrm{Cu}$ in the diets, drinking water, faeces and urine collected in the balance period was assayed using the methods described below.

On T7 and T35 the rats were fasted for $24 \mathrm{~h}$ and anaesthetized with ketamine $(100 \mathrm{mg} / \mathrm{kg}$ body weight) and xylazine $(10 \mathrm{mg} / \mathrm{kg}$ body weight) according to the recommendations for anaesthesia and euthanasia of experimental animals. Then, after laparotomy, blood samples were taken from the caudal vena cava, and finally the rats were euthanized by cervical dislocation. On T7 liver and jejunum, whereas on T35 liver, brain and jejunum were dissected (for histological examination, and for histological examination and $\mathrm{Cu}$ content test in brain and liver, respectively).
Table 3. Composition of mineral mixture (MX) used in experimental diets

\begin{tabular}{|c|c|c|}
\hline Indices & $\begin{array}{l}\text { MX with standard } \\
\text { Cu dosage }^{1}\end{array}$ & $\begin{array}{l}\mathrm{MX} \\
\text { without } \mathrm{Cu}^{2}\end{array}$ \\
\hline \multicolumn{3}{|l|}{ Macroelements, g/kg } \\
\hline \multicolumn{2}{|l|}{ calcium carbonate, anhydrous $\mathrm{CaCO}_{3} 357$} & 357 \\
\hline \multicolumn{3}{|l|}{$\mathrm{K}_{2} \mathrm{HPO}_{4}$} \\
\hline \multirow{2}{*}{$\begin{array}{l}\text { potassium citrate } \mathrm{C}_{6} \mathrm{H}_{5} \mathrm{~K}_{3} \mathrm{O}_{7} \\
\text { sodium chloride } \mathrm{NaCl}\end{array}$} & 70.78 & 70.78 \\
\hline & 74 & 74 \\
\hline \multirow{2}{*}{$\begin{array}{l}\text { potassium sulphate } \mathrm{K}_{2} \mathrm{SO}_{4} \\
\text { magnesium oxide } \mathrm{MgO}\end{array}$} & 46.6 & 46.6 \\
\hline & 24 & 24 \\
\hline microelement mixture & 18 & 18 \\
\hline starch & 213.62 & 213.62 \\
\hline \multicolumn{3}{|l|}{ Microelements, $\mathrm{g} / 100 \mathrm{~g}$} \\
\hline ferric citrate $(16.7 \% \mathrm{Fe})$ & 31 & 31 \\
\hline zinc carbonate $\mathrm{ZnCO}_{3}(56 \% \mathrm{Zn})$ & 4.5 & 4.5 \\
\hline $\begin{array}{l}\text { manganous carbonate } \mathrm{MnCO}_{3} \\
(44.4 \% \mathrm{Mn})\end{array}$ & 23.4 & 23.4 \\
\hline copper carbonate $\mathrm{CuCO}_{3}(55.5 \% \mathrm{Cu})$ & ) 1.85 & 0 \\
\hline potassium iodate $\mathrm{KJ}$ & 0.04 & 0.04 \\
\hline citric acid $\mathrm{C}_{6} \mathrm{H}_{8} \mathrm{O}_{7}$ & 39.21 & 40.7 \\
\hline
\end{tabular}

${ }^{1}$ given to $\mathrm{CuH}$ groups (5 weeks of feeding); ${ }^{2}$ given to $\mathrm{CuL}$ groups (5 weeks of feeding)

\section{$\mathrm{Cu}$ analyses}

$\mathrm{Cu}$ content in water, feed mixture, urine, faeces, brain, and liver samples was determined by an inductively coupled plasma optical emission spectrometry (ICP-OES) (Shimadzu, Kyoto, Japan). A Certified Reference Material NIST-1577C Bovine liver (Merck KGaA, Darmstadt, Germany) was used for quality control.

\section{Blood analyses}

The concentrations of $\mathrm{Cu}, \mathrm{Zn}, \mathrm{Fe}, \mathrm{Ca}, \mathrm{P}$ and $\mathrm{Mg}$ in the blood were determined by ICP-OES. The Certified Reference Material NIST-1577C Bovine liver (Merck KGaA, Darmstadt, Germany) was used for quality control.

Haematological blood parameters, i.e. red blood cells (RBC), haemoglobin (HB), haematocrit (HCT), as well as total white blood cells (WBC) and some WBC subpopulations, were analysed using an automatic haematology analyser (Abacuss Junior Vet, Diatron, Hungary).

The level of rat immunoglobulins (Ig) of classes IgA, IgM and IgE and interleukin (IL)- 6 in the plasma were determined on an ELISA reader (Rayto Life and Analytical Sciences Co., Ltd, Shenzhen, P.R. China) using commercial kits from Elabscience Biotechnology Co., Ltd., Houston, TX, USA).

The content of uric acid (UA), urea (UREA), albumin (ALB), creatinine (CREAT), glucose (GLU), total protein (TP), bilirubin (BIL), total cholesterol 
(TC), high-density lipoprotein (HDL) and triacylglycerols (TG), as well as the activity of alanine aminotransferase (ALT), aspartate aminotransferase (AST), alkaline phosphatase (ALP), creatine kinase (CK), lactate dehydrogenase (LDH) and gammaglutamyl transferase (GGT), were measured using an automatic biochemical analyser (Plasma Diagnostic Instruments Horiba, Kyoto, Japan).

\section{Histological examination of the liver and jejunum}

Samples of the liver and jejunum were cut in two lengthwise and fixed for $24 \mathrm{~h}$ in $5 \%$ formalin, $\mathrm{pH}=7.2$. Within $24 \mathrm{~h}$ the fixed tissue fragments were passed through increasing concentrations of alcohol solutions, acetone and xylene into paraffin blocks in a tissue processor (Leica TP-20, Nussloch, Germany). Paraffin-embedded microscope sections $5 \mu \mathrm{m}$ thick were stained with haematoxylin and eosin (HE staining). Morphometric evaluations of the liver, length of the villi and depth of the crypts were carried out using a computer-assisted microscopic image analysis system. The system consisted of a light microscope (Nikon Eclipse E600, Badhoevedorp, The Netherlands) with a digital camera (Nikon DS-Fi1, Badhoevedorp, The Netherlands) and a PC with image-analysis software (NIS-Elements BR-2.20, Laboratory Imaging, Nikon, Badhoevedorp, The Netherlands). In each jejunum tissue slide, 20 villi cut in two lengthwise and 20 crypts were measured. The length of the villi was measured from the tip to the base.

\section{Statistical analysis}

The obtained numerical data were subjected to statistical analysis using Statistica 10.0 PL software (StatSoft Polska, Krakow, Poland). The following analyses were used: one-way ANOVA (Table 10) and two-way ANOVA (Tables 4-9) to examine the main effects: $\mathrm{L}-$ level of dietary $\mathrm{Cu}$ (two level of dietary $\mathrm{Cu}$ : higher (recommended) $\mathrm{Cu}$ level and reduced $\mathrm{Cu}$ level; $\mathrm{CuH}$ and $\mathrm{CuL}$ treatments, respectively),
$\mathrm{T}$ - feeding period ( 7 and 35 days, respectively), and the interaction between these two factors $(\mathrm{L} \times$ $\mathrm{T})$. If the analysis revealed a significant interaction $(P \leq 0.05)$, the differences among the respective treatment groups were then determined with the Newman-Keuls post-hoc test at $P \leq 0.05$. Treatment effects were considered to be significant at $P \leq 0.05$.

\section{Results}

\section{The effect of the $\mathrm{Cu}$ level in the diet}

Two-way ANOVA analysis showed that in the plasma of the rats from CuL treatment, the contents of $\mathrm{Cu}, \mathrm{Zn}$ and $\mathrm{Fe}(P<0.0001, P=0.048$ and $P=0.047$, respectively) were lower whereas the content of $\mathrm{Mg}$ was higher $(P=0.038)$ than in the rats from $\mathrm{CuH}$ treatment (Table 4). In the blood of the rats receiving $\mathrm{CuL}$ diet, the lower levels of granulocytes $\left(10^{9} / 1\right)$, monocytes $(\%)$ and HCT $(P=0.004, P=0.033$ and $P=0.037$, respectively) were noticed as well as higher levels of WBC and $\operatorname{LYM}\left(10^{9} / 1\right)(P=0.015$ and $P=0.033$, respectively $)$ in comparison to the rats from $\mathrm{CuH}$ treatment (Table 5). The lowered contents of the IgA, IgM and IL-6 $(P<0.0001, P<0.0001$ and $P=0.037$, respectively) in the plasma of the CuL rats were also noticed (Table 6). Moreover, in the plasma of the rats from $\mathrm{CuL}$ treatment decreased contents of GLU and BIL $(P=0.031$ and $P=0.004$, respectively) were found in comparison to $\mathrm{CuH}$ group (Table 7). In $\mathrm{CuL}$ rats, there was an increase in the mean depth of the jejunum crypts $(P=0.024)$ in comparison to rats treated with $\mathrm{CuH}$ (Table 8). There was also an increase in ALP and GGT activities $(P=0.004$ and $P=0.048$, respectively) in the plasma of $\mathrm{CuL}$ rats as compared to rats from $\mathrm{CuH}$ treatment (Table 9).

\section{The effect of the feeding period}

According to two-way ANOVA longer period of feeding (T35) increased the content of $\mathrm{Cu}$

Table 4. Minerals in rat plasma

\begin{tabular}{|c|c|c|c|c|c|c|c|c|}
\hline \multirow[b]{2}{*}{ Indices } & \multicolumn{4}{|c|}{ Subgroups $^{1}$} & \multirow[b]{2}{*}{ SEM } & \multicolumn{3}{|l|}{$P$-value } \\
\hline & CuH-T7 & CuL-T7 & CuH-T35 & CuL-T35 & & $\begin{array}{l}\text { Effect of level of } \\
\text { dietary } \mathrm{Cu}(\mathrm{L})\end{array}$ & $\begin{array}{l}\text { Effect of feeding } \\
\text { period }(T)\end{array}$ & $L \times T$ \\
\hline$\overline{\mathrm{Cu}, \mu \mathrm{mol} / \mathrm{l}}$ & $11.78^{\mathrm{A}}$ & $4.05^{\mathrm{C}}$ & $11.62^{A}$ & $5.61^{B}$ & 0.645 & $<0.0001$ & 0.002 & 0.568 \\
\hline $\mathrm{Zn}, \mu \mathrm{mol} / \mathrm{l}$ & $21.96^{\mathrm{A}}$ & $18.16^{\mathrm{B}}$ & $10.39^{D}$ & $12.33^{\mathrm{C}}$ & 0.718 & 0.048 & $<0.0001$ & 0.052 \\
\hline $\mathrm{Fe}, \mu \mathrm{mol} / \mathrm{l}$ & $37.34^{\mathrm{A}}$ & $34.84^{\mathrm{B}}$ & $37.19^{A}$ & $37.97^{\mathrm{A}}$ & 0.042 & 0.047 & 0.004 & 0.369 \\
\hline $\mathrm{Ca}, \mathrm{mmol} / \mathrm{l}$ & 2.50 & 2.33 & 2.56 & 2.81 & 0.034 & 0.145 & 0.875 & 0.987 \\
\hline $\mathrm{P}, \mathrm{mmol} / \mathrm{l}$ & $3.07^{\mathrm{A}}$ & $3.39^{A}$ & $1.27^{\mathrm{B}}$ & $1.30^{\mathrm{B}}$ & 0.082 & 0.358 & 0.034 & 0.446 \\
\hline $\mathrm{Mg}, \mathrm{mmol} / \mathrm{l}$ & $0.76^{c}$ & $1.30^{\mathrm{A}}$ & $0.90^{\mathrm{B}}$ & $0.90^{\mathrm{B}}$ & 0.065 & 0.038 & 0.365 & 0.062 \\
\hline
\end{tabular}

${ }^{1}$ see Table 2; SEM - standard error of the mean; ${ }^{A-D}$ - means within the same row are significantly different at $P \leq 0.05$ according to NewmanKeul's mean comparison 
Table 5. Haematological indices in rat blood

\begin{tabular}{|c|c|c|c|c|c|c|c|c|}
\hline \multirow[b]{2}{*}{ Indices } & \multicolumn{4}{|c|}{ Subgroups $^{1}$} & \multirow[b]{2}{*}{ SEM } & \multicolumn{3}{|l|}{$P$-value } \\
\hline & CuH-T7 & CuL-T7 & CuH-T35 & CuL-T35 & & $\begin{array}{l}\text { Effect of level of } \\
\text { dietary } \mathrm{Cu}(\mathrm{L})\end{array}$ & $\begin{array}{l}\text { Effect of feeding } \\
\text { period }(\mathrm{T})\end{array}$ & $\mathrm{L} \times \mathrm{T}$ \\
\hline WBC, $10^{9} / l$ & $3.30^{\circ}$ & $4.81^{\mathrm{C}}$ & $6.43^{\mathrm{B}}$ & $7.34^{\mathrm{A}}$ & 0.758 & 0.015 & 0.023 & 0.049 \\
\hline LYM, 109/I & $2.93^{\mathrm{D}}$ & $4.36^{\mathrm{C}}$ & $5.37^{\mathrm{B}}$ & $6.26^{\mathrm{A}}$ & 0.056 & 0.033 & 0.008 & 0.052 \\
\hline MID, $10^{9} / 1$ & $0.10^{B}$ & $0.12^{B}$ & $0.41^{\mathrm{A}}$ & $0.35^{\mathrm{A}}$ & 0.036 & 0.078 & 0.014 & 0.244 \\
\hline GRA, $10^{9} / 1$ & $0.60^{\mathrm{B}}$ & $0.32^{\mathrm{C}}$ & $0.65^{\mathrm{B}}$ & $0.73^{A}$ & 0.024 & 0.004 & 0.036 & 0.655 \\
\hline LYM, \% & 86.31 & 90.63 & 83.91 & 85.03 & 0.124 & 0.391 & 0.065 & 0.088 \\
\hline Ml, \% & $3.04^{B}$ & $2.60^{\circ}$ & $5.03^{\mathrm{A}}$ & $5.15^{\mathrm{A}}$ & 0.065 & 0.033 & 0.008 & 0.072 \\
\hline $\mathrm{GR}, \%$ & $8.13^{B}$ & $6.81^{\mathrm{C}}$ & $9.80^{\mathrm{A}}$ & $9.70^{A}$ & 0.238 & 0.059 & 0.047 & 0.109 \\
\hline $\mathrm{RBC}, 10^{12} / \|$ & $6.26^{\mathrm{B}}$ & $6.20^{\mathrm{B}}$ & $7.87^{\mathrm{A}}$ & $7.87^{\mathrm{A}}$ & 0.071 & 0.092 & 0.024 & 0.062 \\
\hline$H B, g / l$ & $12.16^{\mathrm{B}}$ & $12.01^{B}$ & $13.53^{\mathrm{A}}$ & $13.11^{\mathrm{A}}$ & 0.104 & 0.228 & 0.047 & 0.067 \\
\hline HCT, I/I & $37.03^{B}$ & $36.60^{B}$ & $42.01^{\mathrm{A}}$ & $40.67^{A}$ & 0.133 & 0.037 & 0.004 & 0.234 \\
\hline
\end{tabular}

${ }^{1}$ see Table 2; WBC - white blood cell count; LYM - lymphocytes; GRA - granulocytes; MI - microcytes; RBC - red blood cell count; $\mathrm{HB}$ - haemoglobin content; HCT - haematocrit; SEM - standard error of the mean; ${ }^{\mathrm{A}-\mathrm{D}}$ - means within the same row are significantly different at $P \leq 0.05)$ according to Newman-Keul's mean comparison

Table 6. Immune parameters in rat blood

\begin{tabular}{|c|c|c|c|c|c|c|c|c|}
\hline \multirow[b]{2}{*}{ Indices } & \multicolumn{4}{|c|}{ Subgroups $^{1}$} & \multirow[b]{2}{*}{ SEM } & \multicolumn{3}{|l|}{$P$-value } \\
\hline & CuH-T7 & CuL-T7 & CuH-T35 & CuL-T35 & & $\begin{array}{l}\text { Effect of level } \\
\text { of dietary Cu }(\mathrm{L})\end{array}$ & $\begin{array}{l}\text { Effect of feeding } \\
\text { period }(T)\end{array}$ & $L \times T$ \\
\hline IgA, ng/ml & $94.21^{\mathrm{A}}$ & $84.20^{\mathrm{B}}$ & $73.32^{C}$ & $65.49^{D}$ & 0.323 & $<0.0001$ & $<0.0001$ & 0.053 \\
\hline $\mathrm{lgM}, \mathrm{ng} / \mathrm{ml}$ & $547.3^{c}$ & $486.7^{\circ}$ & $966.7^{\mathrm{A}}$ & $861.4^{\mathrm{B}}$ & 0.623 & $<0.0001$ & $<0.0001$ & 0.083 \\
\hline $\mathrm{lgE}, \mathrm{ng} / \mathrm{ml}$ & $7.40^{A B}$ & $8.04^{\mathrm{A}}$ & $8.02^{\mathrm{A}}$ & $6.94^{\mathrm{B}}$ & 0.108 & 0.059 & 0.077 & 0.038 \\
\hline $\mathrm{IL}-6, \mathrm{pg} / \mathrm{ml}$ & $113.8^{c}$ & $122.0^{C}$ & $168.9^{A}$ & $136.9^{B}$ & 0.824 & 0.037 & 0.006 & 0.061 \\
\hline
\end{tabular}

${ }^{1}$ see Table 2; IgA - immunoglobulin A; IgM - immunoglobulin M; IgE - immunoglobulin E; IL-6 - interleukin 6; ${ }^{A-D}$ - means within the same row are significantly different at $P \leq 0.05$ according to Newman-Keul's mean comparison

Table 7. Parameters of metabolic status in rat plasma

\begin{tabular}{|c|c|c|c|c|c|c|c|c|}
\hline \multirow[b]{2}{*}{ Indices } & \multicolumn{4}{|c|}{ Subgroups $^{1}$} & \multirow[b]{2}{*}{ SEM } & \multicolumn{3}{|l|}{$P$-value } \\
\hline & CuH-T7 & CuL-T7 & $\mathrm{CuH}-\mathrm{T} 35$ & CuL-T35 & & $\begin{array}{l}\text { Effect of level of } \\
\text { dietary } \mathrm{Cu}(\mathrm{L})\end{array}$ & $\begin{array}{l}\text { Effect of feeding } \\
\text { period }(T)\end{array}$ & $L \times T$ \\
\hline $\mathrm{GLU}, \mathrm{mmol} / \mathrm{l}$ & $7.90^{\mathrm{C}}$ & $7.39^{c}$ & $16.89^{A}$ & $14.14^{\mathrm{B}}$ & 0.462 & 0.031 & $<0.0001$ & 0.082 \\
\hline $\mathrm{TP}, \mathrm{g} / \mathrm{l}$ & 7.18 & 6.97 & 5.10 & 4.97 & 0.089 & 0.059 & 0.058 & 0.062 \\
\hline UA, mmol/l & $130.5^{\mathrm{C}}$ & $142.0^{B}$ & $170.0^{A}$ & $167.0^{A}$ & 0.963 & 0.254 & 0.027 & 0.014 \\
\hline UREA, mmol/l & 7.83 & 6.71 & 5.20 & 6.31 & 0.053 & 0.923 & 0.072 & 0.052 \\
\hline CREAT, $\mu \mathrm{mol} / / \mathrm{l}$ & 36.13 & 35.00 & 38.46 & 34.64 & 0.084 & 0.068 & 0.087 & 0.365 \\
\hline $\mathrm{BIL}, \mu \mathrm{mol} / \mathrm{l}$ & $37.63^{\mathrm{B}}$ & $40.52^{A}$ & $31.98^{c}$ & $17.55^{\mathrm{D}}$ & 0.103 & 0.004 & $<0.0001$ & 0.625 \\
\hline$A L B, g / l$ & $3.51^{\mathrm{B}}$ & $3.42^{\mathrm{B}}$ & $4.38^{\mathrm{A}}$ & $3.86^{\mathrm{AB}}$ & 0.044 & 0.265 & 0.044 & 0.064 \\
\hline $\mathrm{TC}, \mathrm{mmol} / \mathrm{l}$ & $3.61^{\mathrm{A}}$ & $3.78^{\mathrm{A}}$ & $1.66^{\mathrm{B}}$ & $1.68^{B}$ & 0.022 & 0.328 & 0.007 & 0.072 \\
\hline $\mathrm{HDL}, \mathrm{mmol} / \mathrm{l}$ & 0.33 & 0.34 & 1.94 & 1.85 & 0.017 & 0.058 & 0.084 & 0.092 \\
\hline $\mathrm{TG}, \mathrm{mmol} / \mathrm{l}$ & $4.86^{\mathrm{B}}$ & $5.71^{\mathrm{A}}$ & $1.83^{\mathrm{C}}$ & $1.61^{\mathrm{C}}$ & 0.054 & 0.345 & 0.034 & 0.365 \\
\hline
\end{tabular}

${ }^{1}$ see Table 2; GLU - glucose; TP - total protein; UA - uric acid; UREA - urea; CREAT - creatinine; BIL - bilirubin; ALB - albumin; TC - total cholesterol; HDL - HDL cholesterol; TG - triacylglycerols; ${ }^{A-D}$ - means within the same row are significantly different at $P \leq 0.05$ according to Newman-Keul's mean comparison

Table 8. Measurements of jejunal villi and crypts in experimental rats

\begin{tabular}{|c|c|c|c|c|c|c|c|c|}
\hline \multirow[b]{2}{*}{ Indices } & \multicolumn{4}{|c|}{ Subgroups ${ }^{1}$} & \multirow[b]{2}{*}{ SEM } & \multicolumn{3}{|l|}{$P$-value } \\
\hline & CuH-T7 & CuL-T7 & CuH-T35 & CuL-T35 & & $\begin{array}{l}\text { Effect of level } \\
\text { of dietary Cu (L) }\end{array}$ & $\begin{array}{l}\text { Effect of feeding } \\
\text { period }(T)\end{array}$ & $\mathrm{L} \times \mathrm{T}$ \\
\hline $\begin{array}{l}\text { Mean length of villin } \\
\text { the jejunum, } \mu \mathrm{m}\end{array}$ & $394.8^{B}$ & $368.8^{B}$ & $542.5^{A}$ & $562.1^{\mathrm{A}}$ & 0.892 & 0.842 & $<0.0001$ & 0.364 \\
\hline $\begin{array}{l}\text { Mean depth of crypt } \\
\text { in the jejunum, } \mu \mathrm{m}\end{array}$ & $107.0^{\mathrm{B}}$ & $113.6^{\mathrm{B}}$ & $144.2^{\mathrm{A}}$ & $154.4^{\mathrm{A}}$ & 0.631 & 0.024 & 0.003 & 0.077 \\
\hline
\end{tabular}

\footnotetext{
${ }^{1}$ see Table 2; ${ }^{A-B}$ - means within the same row are significantly different at $P \leq 0.05$ according to Newman-Keul's mean comparison
} 
Table 9. Activity of biochemical enzymes in rat plasma

\begin{tabular}{|c|c|c|c|c|c|c|c|c|}
\hline \multirow[b]{2}{*}{ Indices } & \multicolumn{4}{|c|}{ Subgroups $^{1}$} & \multirow[b]{2}{*}{ SEM } & \multicolumn{3}{|l|}{$P$-value } \\
\hline & CuH-T7 & CuL-T7 & CuH-T35 & CuL-T35 & & $\begin{array}{l}\text { Effect of level of } \\
\text { dietary } \mathrm{Cu}(\mathrm{L})\end{array}$ & $\begin{array}{l}\text { Effect of feeding } \\
\text { period }(T)\end{array}$ & $L \times T$ \\
\hline$\overline{\mathrm{AST}}, \mathrm{U} / \mathrm{l}$ & $87.68^{B}$ & $91.84^{\mathrm{A}}$ & $62.50^{c}$ & $59.31^{c}$ & 0.882 & 0.682 & 0.005 & 0.209 \\
\hline ALT, U/I & $50.94^{A}$ & $53.23^{A}$ & $38.62^{B}$ & $35.26^{B}$ & 0.364 & 0.621 & 0.003 & 0.053 \\
\hline ALP, U/I & $449.4^{\mathrm{D}}$ & $487.6^{C}$ & $678.5^{\mathrm{B}}$ & $728.0^{A}$ & 0.908 & 0.004 & $<0.0001$ & 0.012 \\
\hline GGT, U/l & $3.21^{\mathrm{D}}$ & $4.60^{C}$ & $6.93^{\mathrm{A}}$ & $6.16^{\mathrm{B}}$ & 0.234 & 0.048 & $<0.0001$ & 0.023 \\
\hline CK, U/I & 0.02 & 0.03 & 0.03 & 0.02 & 0.003 & 0.896 & 0.482 & 0.073 \\
\hline LDH, U/I & $1381^{\mathrm{A}}$ & $1353^{\mathrm{A}}$ & $1152^{\mathrm{B}}$ & $1140^{B}$ & 0.894 & 0.364 & 0.004 & 0.058 \\
\hline
\end{tabular}

${ }^{1}$ see Table 2; AST - aspartate aminotransferase; ALT - alanine aminotransferase; ALP - alkaline phosphatase; GGT - $\gamma$-glutamyl transferase; $\mathrm{CK}$ - creatine kinase; $\mathrm{LDH}$-lactate dehydrogenase; ${ }^{\mathrm{A}-\mathrm{D}}$ - means within the same row are significantly different at $P \leq 0.05$ according to NewmanKeul's mean comparison

and Fe $(P=0.002$ and $P=0.004$, respectively $)$ and decreased $\mathrm{Zn}$ and $\mathrm{P}$ contents $(P<0.0001$ and $P=0.034$, respectively) in comparison to T7 feeding period (Table 4). There was also an increase in WBC, LYM $\left(10^{9} / 1\right)$, MID, GRA, MI, GR, RBC, HB and HCT levels $(P=0.023, P=0.008$, $P=0.014, P=0.036, P=0.008, P=0.047, P=0.024$, $P=0.047$ and $P=0.004$, respectively) in the blood of rats from T35 group (Table 5). Higher levels of IgM and IL-6 $(P<0.0001$ and $P=0.006$, respectively $)$ and lower IgA content $(P<0.0001)$ in the blood of rats under the influence of T35 feeding period in comparison to $\mathrm{T} 7$ feeding period were determined (Table 6). In addition, the two-way ANOVA revealed that feeding rats for 35 days increased the contents of GLU, UA and ALB $(P<0.0001, P=$ 0.027 and $P=0.044$, respectively) as well as decreased the contents of BIL, TC and TG $(P<0.0001$, $P=0.007$ and $P=0.034$, respectively) as compared to $\mathrm{T} 7$ feeding period (Table 7). Feeding rats for a 35-day period resulted in an increase in both the depth of the crypts and the villi length of the jejunum ( $P<0.0001$ and $P=0.003$, respectively) in comparison to T7 feeding period (Table 8 ). Furthermore, lower AST, ALT and LDH activity $(P=$ $0.005, P=0.003$ and $P=0.004$, respectively) and higher ALP and GGT activities $(P>0.0001$, both) were also found in rats fed for 35 days (Table 9). Extended (T35) period of feeding CuL diets resulted in decreased plasma content of $\mathrm{Cu}$ $(P=0.002$; Table 4), IgA, IgM, IL-6 $(P<0.001$, $P<0.001$ and $P=0.006$, respectively; Table 6) and BIL $(P<0.0001$; Table 7$)$, as well as activity of GGT $(P>0.0001$; Table 9$)$. However, after the 35day period of feeding $\mathrm{CuL}$ diet increased contents of $\mathrm{Zn}(P<0.0001$; Table 4$)$, WBC, LYM $\left(10^{9} / 1\right)$ and GRA $(P=0.023, P=0.008$ and $P=0.036$, respectively; Table 5) as well as activity of ALP $(P>0.0001$; Table 9) were noted in comparison to $\mathrm{CuH}$ group.

\section{The effect of $\mathrm{Cu}$ level in the diet on the $\mathrm{Cu}$ biodistribution}

Data on the biodistribution of $\mathrm{Cu}$ in the rats are presented in Table 10. A significant reduction in total excretion of $\mathrm{Cu}$ in the urine and faeces $(P<0.0001)$ of rats receiving $\mathrm{CuL}$ diet in relation to the rats receiving $\mathrm{CuH}$ diet containing the recommended quantity of this element was shown. It was caused by significant decrease in the level of $\mathrm{Cu}$ excretion in the faeces $(P<0.0001)$ in the $\mathrm{CuL}$ rats as compared to the $\mathrm{CuH}$ group, despite an increase in urinary excretion of $\mathrm{Cu}(P=0.003)$ by the $\mathrm{CuL}$ rats in comparison to the $\mathrm{CuH}$ rats. Thus, the $\mathrm{Cu}$ digestibility index was significantly higher $(P<0.0001)$ in the rats from the $\mathrm{CuL}$ treatment than in the $\mathrm{CuH}$ group. The $\mathrm{Cu}$ utilisation index, which takes into account the loss of $\mathrm{Cu}$ in both faeces and urine, was lower $(P=0.009)$ in the rats from the $\mathrm{CuL}$ treatment

Table 10. Copper excretion in the digestibility and utilization tests (5-day balance test performed during feeding period after a 10-day preliminary period), and $\mathrm{Cu}$ concentration in liver and brain tissues in rats fed experimental diets for 35 days

\begin{tabular}{|c|c|c|c|c|}
\hline \multirow{2}{*}{ Indices } & \multicolumn{2}{|c|}{ Level of dietary $\mathrm{Cu}^{1}$} & \multirow{2}{*}{ SEM } & \multirow{2}{*}{$P$-value } \\
\hline & $\mathrm{CuH}$ & CuL & & \\
\hline Cu in diet, mg/kg & $0.47^{\mathrm{A}}$ & $0.31^{\mathrm{B}}$ & 0.065 & $<0.0001$ \\
\hline Diet intake, $\mathrm{g} / 5 \mathrm{~d}$ & 75.82 & 79.81 & 4.000 & 0.359 \\
\hline Cu intake from diet, $\mathrm{mg} / 5 \mathrm{~d}$ & $6.21^{\mathrm{A}}$ & $3.85^{\mathrm{B}}$ & 0.080 & $<0.0001$ \\
\hline Total Cu intake ${ }^{2}, \mathrm{mg} / 5 \mathrm{~d}$ & $0.47^{\mathrm{A}}$ & $0.31^{\mathrm{B}}$ & 0.080 & $<0.0001$ \\
\hline Cu in urine, $\mathrm{mg} / 5 \mathrm{~d}$ & $0.17^{\mathrm{B}}$ & $0.24^{\mathrm{A}}$ & 0.015 & 0.003 \\
\hline $\mathrm{Cu}$ in faeces, $\mathrm{mg} / 5 \mathrm{~d}$ & $0.27^{\mathrm{A}}$ & $0.02^{\mathrm{B}}$ & 0.009 & $<0.0001$ \\
\hline Total Cu excretion, $\mathrm{mg} / 5 \mathrm{~d}$ & $0.44^{\mathrm{A}}$ & $0.26^{\mathrm{B}}$ & 0.099 & $<0.0001$ \\
\hline Cu utilization \% & $7.43^{\mathrm{B}}$ & $17.66^{\mathrm{A}}$ & 0.548 & 0.009 \\
\hline Cu digestibility, \% & $43.42^{B}$ & $94.48^{\mathrm{A}}$ & 1.992 & $<0.0001$ \\
\hline $\mathrm{Cu}$ in liver, $\mathrm{mg} / \mathrm{kg}^{3}$ & $3.36^{\mathrm{A}}$ & $0.92^{\mathrm{B}}$ & 0.836 & $<0.0001$ \\
\hline $\mathrm{Cu}$ in brain, $\mathrm{mg} / \mathrm{kg}^{3}$ & 4.69 & 3.87 & 0.637 & 0.077 \\
\hline
\end{tabular}

${ }^{1}$ see Table 2; ${ }^{2}$ total $\mathrm{Cu}$ intake from diet and water (Cu concentration in water administered to rats was $0.0182 \mathrm{mg} / \mathrm{l}) ;{ }^{3} \mathrm{Cu}$ content day 35 of the experiment; $A, B$ - means within the same row are significantly different at $P \leq 0.05$ according to Newman-Keul's mean comparison 

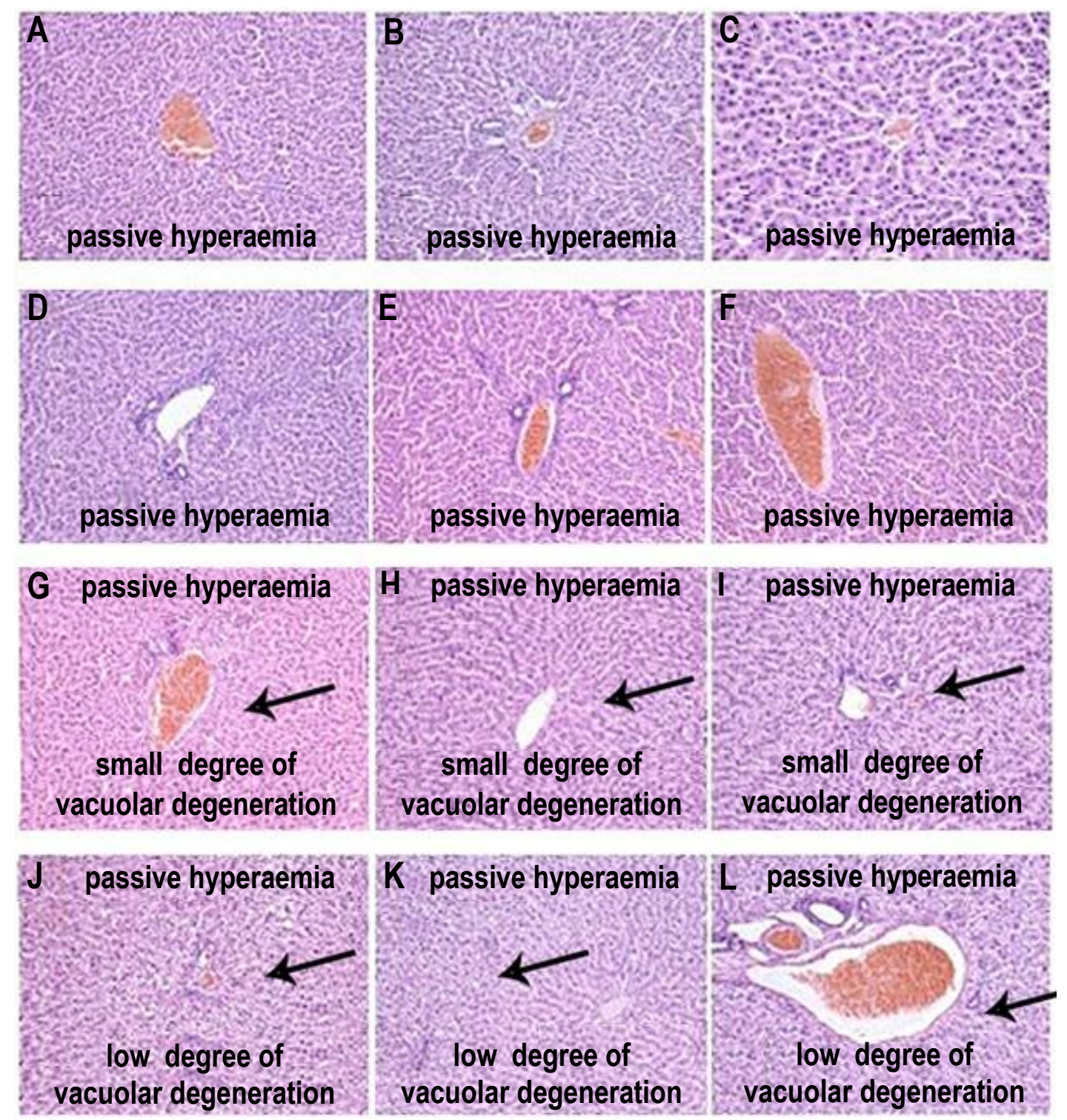

Figure 1. Morphological effects of adequate $(\mathrm{CuH})$ or deficient $(\mathrm{CuL})$ dose of $\mathrm{Cu}$ in the diet on rat liver on day 7 and 35 of the experiment. (A-D) CuL group on day 7 of the experiment - most of the livers showed no histopathological changes; in 2 livers slight passive hyperaemia was observed; $(E-G)$ CuH group on day 7 of the experiment - most of the livers showed no histopathological changes; in 3 livers slight passive hyperaemia was observed; $(\mathrm{H}-\mathrm{I}) \mathrm{CuL}$ group on day 35 of the experiment - passive hyperaemia, small degree of vacuolar degeneration; (J-L) $\mathrm{CuH}$ group on day 35 of the experiment - passive hyperaemia, high degree of vacuolar degeneration

than in those from the $\mathrm{CuH}$ group. In the $\mathrm{CuL}$ rats, there was also a reduction in the hepatic $\mathrm{Cu}$ content $(P<0.0001)$ as compared to the rats from the $\mathrm{CuH}$ group. However, there was no effect of experimental treatments on the content of $\mathrm{Cu}$ in the rat brain (Table 10).

\section{The effect of $\mathrm{Cu}$ level in the diet and feeding period on the histology of the liver}

On T7 there were also no significant differences found in the liver morphology of the rats from the $\mathrm{CuL}$ treatment (Figure 1). Histopathological examination on T35 showed passive hyperaemia and a small degree of vacuolar degeneration in the rats from the $\mathrm{CuL}$ group, whereas in the rats receiving the standard level of $\mathrm{Cu}$ in the diet the degree of vacuolar degeneration was high.

\section{Discussion}

The results of our study showed that a reduced level of $\mathrm{Cu}$ in the rat diet increased the excretion of $\mathrm{Cu}$ in the urine with a simultaneous drastic reduction in the quantity of $\mathrm{Cu}$ excreted in the faeces. Consequently, it resulted in a significantly lower level of total $\mathrm{Cu}$ excretion in comparison to rats fed a diet containing the recommended $\mathrm{Cu}$ level. 
Increasing $\mathrm{Cu}$ excretion in urine indicates that this element was absorbed in the gastrointestinal tract, undergone metabolic processes in the body and then was excreted. In turn, the excess of ingredients which haven't been absorbed in the gastrointestinal tract is excreted in the faeces. The results of our research have also shown that a reduced level of $\mathrm{Cu}$ in the rat diet caused this element retention percentage and digestibility increasement as compared to the group receiving the recommended amount of $\mathrm{Cu}$ in the diet.

Similarly, Lee et al. (2016) noted a significant reduction in the amount of $\mathrm{Cu}$ excreted by rats receiving a Cu-poor diet for 28 days as compared to rats receiving $\mathrm{Cu}$ nanoparticles $(25 \mathrm{~nm})$ orally at 100 , 200 or $400 \mathrm{mg} / \mathrm{kg} \mathrm{BW}$. Arnal et al. (2014), who fed rats a Cu-poor (trace amounts) diet for 30 days, noted lower excretion of $\mathrm{Cu}$ in the faeces in relation to the control group fed a diet that fully satisfied the need for this microelement. The results of our research, confirming the observations of other authors (Arnal et al., 2014; Lee et al., 2016), suggest that in the rat body better supplied mineral is used (with reduced excretion in the faeces which is supposed to prevent shortages). It is likely that the small amounts of this element present in the natural components of the diet (starch, casein, oil, etc.) can be successfully absorbed by the body. These assumptions are confirmed by the lack of variation in the amount of feed consumed, body weight, and relative weight of selected internal organs between the two experimental groups (unpublished data).

Numerous studies indicate that the liver, kidneys and brain are the organs in which the most $\mathrm{Cu}$ is accumulated (Ozkul et al., 2011; Arnal et al., 2014; Kumar et al., 2015; Seol et al., 2015). Seol et al. (2015) reported a decrease in $\mathrm{Cu}$ content in the liver of mice fed a Cu-deficient diet $(0.93 \mathrm{mg} \mathrm{Cu} / \mathrm{kg})$ for 11 weeks in relation to controls receiving the recommended dose of $\mathrm{Cu}(6.36 \mathrm{mg} \mathrm{Cu} / \mathrm{kg})$ in the diet. In a study by Lee et al. (2016) it was also shown lower $\mathrm{Cu}$ content in the liver, kidneys, spleen, brain, lungs and heart of rats fed a $\mathrm{Cu}$-deficient diet for 28 days as compared to animals receiving 100,200 or $400 \mathrm{mg} \mathrm{Cu} / \mathrm{kg}$ by gavage. The results of our study confirm that the $\mathrm{Cu}$ content in the liver of the rats decreased as a consequence of eliminating the $\mathrm{CuCO}_{3}$ supplement from their diet. However, no significant differences were found in the content of this element in the brain between the two experimental groups. There are no statistically significant differences in the accumulation of $\mathrm{Cu}$ in the brain of both experimental groups probably due to the fact that the used dose corresponded to recommended one or was lower than recommended, and therefore was too low to cause accumulation of this element in the brain. In turn, the liver is an organ through which all chemical compounds present in food pass through, therefore first of all cumulative processes occur in it. The differences observed in $\mathrm{Cu}$ accumulation in the brain and the liver may be due to the fact that $\mathrm{Cu}$ transported from peripheral blood to the brain must overcome the blood-brain barrier (BBB). Therefore, it may be assumed that due to this additional protection, $\mathrm{Cu}$ is accumulated in the brain slower than in the liver. So, to obtain visible changes in the level of $\mathrm{Cu}$ in the brain between the two experimental groups a lot of time is needed (Scheiber et al., 2014).

$\mathrm{Cu}^{+}$and $\mathrm{Cu}^{2+}$ ions present in the lumen of the small intestine are absorbed into the enterocytes mainly by means of $\mathrm{Cu}$ transporter 1 (CTR1), and to a lesser extent divalent metal transporter 1 (DMT1). From the enterocytes, $\mathrm{Cu}^{2+}$ ions enter the blood by means of copper-transporting ATPases ATP7A and ATP7B (Ognik et al., 2016). The results of our research have shown that a lowered $\mathrm{Cu}$ level in the diet is reflected in a decrease in the content of this element in the plasma of rats. Similarly, Ozkul et al. (2011) reported significantly lower content of this microelement in rats receiving a diet without $\mathrm{Cu}$ for 28 days than in animals fed a diet containing $15 \mathrm{mg} \mathrm{Cu} / \mathrm{kg}$ during this period.

A deficiency of $\mathrm{Cu}$ in the body, especially during its intensive growth, may also adversely affect the absorption of other micronutrients, disrupting the functioning of the entire body (Ajayi, 2005). Scientific research demonstrates that a deficiency of $\mathrm{Cu}$ negatively affects absorption of $\mathrm{Fe}$, resulting in disorders of its metabolism, and consequently the development of anaemia and the accumulation of this micronutrient in the liver. This is presumed to be a consequence of reduced activity of $\mathrm{Cu}$-dependent enzymes such as ceruloplasmin or hephaestin, which are responsible for the proper distribution and metabolism of $\mathrm{Fe}$ (Vulpe et al., 1999; Pyatskowit and Prohaska, 2008). This was confirmed by the results of our study, which showed a reduction in the plasma content of Fe under the effect of using a reduced level of $\mathrm{Cu}$ in the diet for 7 days. Nevertheless, along with the extension of the period of the administration of experimental diet, the level of $\mathrm{Fe}$ in the plasma has stabilized.

Our study also showed an increase of $\mathrm{Mg}$ content in the plasma of rats under the effect of reducing the level of $\mathrm{Cu}$ in the diet but only at T7. At T35 no such effect was observed. Maintaining an appropriate level of this element in the body is very important, because 
as an activator of numerous enzymes, it participates in many metabolic processes such as protein transformations and energy production (Ajayi, 2005). The results of our research, however, indicate that a lowered level of $\mathrm{Cu}$ in the rat diet activates adaptation mechanisms that prevent disruption of the absorption and metabolism of important micronutrients, as indicated by the increase in the level of $\mathrm{Cu}$ in the blood plasma of rats receiving a diet with a reduced level of $\mathrm{Cu}$ as a result of the extension of the experimental period. In our study we have also shown a reduction in the level of $\mathrm{P}$ in the blood plasma of rats after experimental period extension, where the values of these indicators did not differ significantly between the two experimental groups in both experimental terms. Therefore, it may be assumed that changes in the content of this microelement in the blood of rats were not caused by the applied treatments, but they were physiological and related to the rat growth process. Our study have also shown that content of $\mathrm{Zn}$ was decreased in $\mathrm{CuL}$ treatment in comparison to $\mathrm{CuH}$ treatment at $\mathrm{T} 7 \mathrm{but}$ elongated feeding period (T35) caused an increased content of this microelement in the blood of CuL rats in comparison to $\mathrm{CuH}$ group. $\mathrm{Zn}$ is a component of many proteins, including important enzymes such as $\mathrm{Cu}-\mathrm{Zn}-\mathrm{SOD}$ (Andreini et al., 2006). It also plays a crucial role in the synthesis of insulin and regulation of its secretion, as well as glucagon secretion (Donangelo and King, 2012). The available literature proves that between $\mathrm{Cu}$ and $\mathrm{Zn}$ an antagonism may occur (Evliyaoğlu et al. 2004). In our study the antagonistic effect of $\mathrm{Cu}$ on the level of $\mathrm{Zn}$ was revealed only at T35.

The available data shows that too low level of $\mathrm{Cu}$ in the diet may also result in the development of anaemia and neutropenia (Harless et al., 2006; Matak et al., 2013; Wazir and Ghobrial, 2017). This is probably due to the reduced activity of $\mathrm{Cu}$-dependent enzymes responsible for the proper maturation of haematopoietic cells and to less efficient utilization of Fe (Harless et al., 2006). However, our results indicate that the reduction of the $\mathrm{Cu}$ level did not exert negative effect on haematological parameters in rats. The lack of differences between $\mathrm{CuL}$ and $\mathrm{CuH}$ groups both in $\mathrm{T} 7$ and $\mathrm{T} 35$ indicates that such $\mathrm{Cu}$ reduction in the diet did not influence haematological parameters. And the observed changes between T7 and T35 (regardless $\mathrm{Cu}$ level) are connected with animals growing.

The available literature proves that the negative effect of $\mathrm{Cu}$ deficiency on innate and acquired immunity may also be manifested as inhibition of IL-2 secretion and proliferation of activated $\mathrm{T}$ lympho- cytes, as well as impairment of respiratory burst and the activity of phagocytic cells (Huang and Failla, 2000; Smith et al., 2008). Cu deficiency probably also modifies the secretion of inflammatory mediators, such as tumour necrosis factor $\alpha$ (TNF- $\alpha$ ), interleukins (IL-1 and IL-6) and prostaglandin $\mathrm{E}_{2}$ $\left(\mathrm{PGE}_{2}\right)$ (Huang and Failla, 2000). The results of our study indicate that extending the time of feeding rats experimental diets, regardless of the level of $\mathrm{Cu}$, increases the level of WBC, LYM and GRA, however, the values of these parameters are clearly higher for rats treated with $\mathrm{CuL}$, which may indicate that $\mathrm{Cu}$ deficiency in the rat diet intensifies inflammatory processes in the body. On the other hand, the opposite trend was observed for IgM and IL-6 levels in rat blood plasma. Extension of the experimental period resulted in increased levels of these indicators, however in the $\mathrm{CuL}$ group IgM and IL-6 values were lower than in the $\mathrm{CuH}$ group. In addition, in the rats from $\mathrm{CuL}$ treatment lower IgA levels were observed at both experimental terms. This may suggest that the level of immune status indicators may change physiologically with the growth of rats. However, the lower level of immunoglobulins may indicate a shortage of humoral immunity (Gonzalez-Quintela et al., 2008). The increase in WBC also confirms a decrease in immunity. Although the content of IL-6, which is an indicator of the inflammatory process, decreased, the level of this indice increases only in strong inflammatory states (Tanaka et al., 2014). Therefore, our results are difficult to interpret, however, it may be assumed that these changes may be the initial reaction suggesting a weakened immunity in response to a reduced amount of $\mathrm{Cu}$ in the diet. Therefore, further studies on longer time of administration of experimental diets in order to clearly determine the direction of changes in the immune response in rats are needed.

Extending the time during which the rats were subjected to the $\mathrm{CuL}$ treatment (lack of $\mathrm{CuCO}_{3}$ supplementation) caused a decrease in the IgE level relative to the control at $\mathrm{T} 35$, which was not observed in $\mathrm{T} 7$ period. An increase in the level of IgE in the blood usually accompanies allergic reactions (Manohar and Selvakumaran, 2012). Although $\mathrm{Cu}$ is thought to rarely cause allergies and to have low allergenic potential, it cannot be ruled out that when introduced to the body it may cause minor allergic reactions (Wöhrl et al., 2001). This would explain the higher level of IgE in the blood of rats receiving the recommended dosage of $\mathrm{CuCO}_{3}$ as compared to animals whose diet was not supplemented with this element. 
There is little information on the effect of $\mathrm{Cu}$ poor diet on the biochemical parameters of plasma in rats. The extension of the use of both experimental treatments has reduced the levels of GLU and ALB in the blood plasma of rats, however their lower values were stated in the $\mathrm{CuL}$ group. Albumins perform many important functions in the body: they participate in the transport of metals, fatty acids, cholesterol, and bile pigments and regulate osmotic pressure and the distribution of fluids between compartments. Albumin is also the main antioxidant in plasma, whose components are constantly exposed to reactive oxygen species (ROS) (Roche et al., 2008). It may be assumed that although changes in ALB level are undoubtedly physiological (increasing the level of this indicator in both groups over time) by lowering the level of $\mathrm{Cu}$ in the rat diet may weaken the antioxidant status of the body.

According to the results of the study by Lei et al. (2008) the level of $\mathrm{Cu}$ in the diet increases as the level of BIL increases. Our research confirms this raport. There was noticed a significant decrease in the level of BIL in the blood of $\mathrm{CuL}$ rats relative to the $\mathrm{CuH}$ rats at T35. BIL is currently considered an important endogenous antioxidant, whose low level may promote heart disease, stroke and dementia (Bulmer et al., 2008). This is another proof that the deficit of $\mathrm{Cu}$ in the rat diet may negatively affect the body by weakening the antioxidant defence. Also, low level of $\mathrm{Cu}$ in the diet may adversely affect lipid metabolism and lead to an increase in the TG, TC or LDL levels in serum (Kaya et al., 2006; Burkhead and Lutsenko, 2013; Megahed et al., 2014). However, the results of our research do not confirm these reports. We have shown a decrease in the level of TC and TG in the blood plasma of rats as a result of the extension of the experimental period both in the $\mathrm{CuH}$ and $\mathrm{CuL}$ groups. The lack of differences in the values of these parameters between the two experimental groups suggests that these changes were physiological changes occurring in the body of growing animals, and did not depend on the $\mathrm{Cu}$ level in the diet.

Excessive accumulation of $\mathrm{Cu}^{+}$and $\mathrm{Cu}^{2+}$ ions introduced into the body via the digestive tract may lead to adverse functional and structural changes in important internal organs, including liver and kidneys (Liao and Liu, 2012; Lee et al., 2016). Our results showed an increase in the activity of liver enzymes ALP and GGT in the plasma of the rats as a consequence of T35 feeding period wherein ALP activity increased particularly in rats from the $\mathrm{CuL}$ group, whereas GGT activity showed the opposite tendency and was higher in the $\mathrm{CuH}$ group than CuL. The activity of enzymes such as AST and ALT was decreased in comparison to $\mathrm{CuH}$ rats, which suggests that these changes were physiological and were associated with the process of animal growth. Therefore, it may be assumed, that various enzymes react differently to the level of $\mathrm{Cu}$ in the diet. Both excess and deficiency of $\mathrm{Cu}$ negatively affect the enzymatic profile of the body. Furthermore, histopathological examination of the liver in the $\mathrm{CuL}$ rats on day 35 of the experiment showed only passive hyperaemia of the liver tissue accompanied by a small degree of vacuolar degeneration, while in rats receiving the recommended dosage of $\mathrm{Cu}$ in the diet a high degree of degeneration of liver tissue was observed. Similarly, Tomaszewska et al. (2014), administering $\mathrm{Cu}$ to rats at a level meeting $100 \%$ or $75 \%$ of the daily requirement for 30 days, noted an increase in the number of apoptotic cells and in ballooning degeneration of hepatocytes in the livers, while the livers of rats receiving only $25 \%$ of the daily $\mathrm{Cu}$ requirement in the diet did not show similar changes. In addition, in our study there was found an increase in the length of the intestinal villi and depth of intestinal crypts when feeding period was extended regardless $\mathrm{Cu}$ dose. Therefore, it may be assumed that the level of $\mathrm{Cu}$ present in the natural components of the diet was sufficient to maintain normal morphology and functioning of the intestines in rats. In addition, the changes in intestinal morphology observed during the experiment are physiological and related to the growth of rats.

The similar effect of using $\mathrm{CuH}$ and $\mathrm{CuL}$ diets observed in our studies over a period of 35 days to increase or decrease the level of some blood indicators, as well as intestinal morphometry, suggests that this is the effect of physiological changes in these ratios in growing rats. Rats commonly used in experimental models usually aged $8-12$ weeks. So, these are young specimens that still have many developmental processes, including hormonal balance stabilization lymphocytes $\mathrm{T}$ maturation or nervous system development (Jackson et al., 2017). All these processes can have a significant impact on changes stated for indicators determined in our study.

\section{Conclusions}

The obtained results indicate that rats have the ability to physiologically adapt to a short-term (35-day) diet with a reduced level of $\mathrm{Cu}$, because reducing the level of this element in the diet is regulated by biodistribution mechanisms and reduced excretion of it from the body. However, the 35-day period of 
feeding diet with a reduced content of $\mathrm{Cu}$ caused changes in many indicators of the immune and biochemical systems - weakness of immune response and the bilirubin and albumin metabolisms that play an antioxidant role in the body. The obtained results of the study may also depend to a large extent on the process of rat growth, therefore it may not be assumed that $\mathrm{Cu}$ supplementation in rats is completely unnecessary. Therefore, further studies are necessary to determine the optimal dose of $\mathrm{Cu}$ in the diet, as well as its long-term effect on the rat body.

\section{References}

Ajayi O.B., 2005. Micronutrient changes in some tissues of copper deficient rats. Pak. J. Nutr. 4, 123-125, https://doi.org/10.3923/ pjn.2005.123.125

Al-Naimi R.A., Al-Tayar N.H., Abdul-Hadi D., 2010. Toxicopathological study due to effect of different doses of copper sulfate ingested in rat. Al-Anbar J. Vet. Sci. 3, 1-16

Andreini C., Banci L., Bertini I., Rosato A., 2006. Counting the zincproteins encoded in the human genome. J. Proteome Res. 5, 196-201, https://doi.org/10.1021/pr050361j

Aoki T., 2004. Copper deficiency and the clinical practice. Japan Med. Assoc. J. 47, 365-370

Arnal N., Dominici L., de Tacconi M.J.T., Marra C.A., 2014. Copperinduced alterations in rat brain depends on route of overload and basal copper levels. Nutrition 30, 96-106, https://doi. org/10.1016/j.nut.2013.06.009

Bulmer A.C., Blanchfield J.T., Toth I., Fassett R.G., Coombes J.S., 2008. Improved resistance to serum oxidation in Gilbert's syndrome: a mechanism for cardiovascular protection. Atherosclerosis 199, 390-396, https://doi.org/10.1016/j.atherosclerosis.2007.11.022

Burkhead J.L., Lutsenko S., 2013. The role of copper as a modifier of lipid metabolism. In: R.V. Baez (Editor). Lipid Metabolism. IntechOpen. London (UK), pp. 39-60, https://doi. org/10.5772/51819

Cholewińska E., Juśkiewicz J., Ognik K., 2018a. Comparison of the effect of dietary copper nanoparticles and one copper (II) salt on the metabolic and immune status in a rat model. $\mathrm{J}$. Trace Elem. Med. Biol. 48, 111-117, https://doi.org/10.1016/j. jtemb.2018.03.017

Cholewińska E., Ognik K., Fotschki B., Zduńczyk Z., Juśkiewicz J., 2018b. Comparison of the effect of dietary copper nanoparticles and one copper (II) salt on the copper biodistribution and gastrointestinal and hepatic morphology and function in a rat model. PLoS One 13, e0197083, https://doi.org/10.1371/journal.pone. 0197083

Collins J.F., Prohaska J.R., Knutson M.D., 2010. Metabolic crossroads of iron and copper. Nutr. Rev. 68, 133-147, https://doi. org/10.1111/j.1753-4887.2010.00271.x

Dake Y., Amemiya T., 1991. Electron microscopic study of the optic nerve in copper deficient rats. Exp. Eye Res. 52, 277-181, https://doi.org/10.1016/0014-4835(91)90091-R

Deibel M.A., Ehmann W.D., Markesbery W.R., 1996. Copper, iron, and zinc imbalances in severely degenerated brain regions in Alzheimer's disease: possible relation to oxidative stress. J. Neurol. Sci. 143, 137-142, https://doi.org/10.1016/S0022$510 \times(96) 00203-1$
Donangelo C.M., King J.C., 2012. Maternal zinc intakes and homeostatic adjustments during pregnancy and lactation. Nutrients 4, 782-798, https://doi.org/10.3390/nu4070782

Evliyaoğlu O., Kebapçılar L., Uzuncan N., Kılıçaslan N., Karaca B., Kocaçelebi R., Yensel N., 2004. Correlations of serum $\mathrm{Cu}^{+2}$, $\mathrm{Zn}^{+2}, \mathrm{Mg}^{+2}$ and $\mathrm{HbA}_{1 \mathrm{c}}$ in type 1 and type 2 diabetes mellitus. Turk. J. Endocrinol. Metab. 2, 75-79

Gaetke L.M., Chow C.K., 2003. Copper toxicity, oxidative stress, and antioxidant nutrients. Toxicology 189, 147-163, https://doi. org/10.1016/S0300-483X(03)00159-8

Gonzalez-Quintela A., Alende R., Gude F., Campos J., Rey J., Meijide L.M., Fernandez-Merino C., Vidal C., 2008. Serum levels of immunoglobulins ( $\lg G, \lg A, \lg M)$ in a general adult population and their relationship with alcohol consumption, smoking and common metabolic abnormalities. Clin. Exp. Immunol. 151, 42-50, https://doi.org/10.1111/j.13652249.2007.03545.x

Harless W., Crowell E., Abraham J., 2006. Anemia and neutropenia associated with copper deficiency of unclear etiology. Am. J. Hematol. 81, 546-549, https://doi.org/10.1002/ajh.20647

Huang Z.L., Failla M.L., 2000. Copper deficiency suppresses effector activities of differentiated U937 cells. J. Nutr. 130, 1536-1542, https://doi.org/10.1093/jn/130.6.1536

Jackson S.J., Andrews N., Ball D. et al., 2017. Does age matter? The impact of rodent age on study outcomes. Lab. Anim. 51, 160-169, http://doi.org/10.1177/0023677216653984

Jaiser S.R., Winston G.P., 2010. Copper deficiency myelopathy. J. Neurol. 257, 869-881, https://doi.org/10.1007/s00415010-5511-x

Kaya A., Altıner A., ÖZpınar A., 2006. Effect of copper deficiency on blood lipid profile and haematological parameters in broilers. J. Vet. Med. A-Physiol. Pathol. Clin. Med. 53, 399-404, https://doi.org/10.1111/j.1439-0442.2006.00835.x

Kim B.-E., Nevitt T., Thiele D.J., 2008. Mechanisms for copper acquisition, distribution and regulation. Nat. Chem. Biol. 4, 176-185, https://doi.org/10.1038/nchembio.72

Klevay L.M., 2008. Alzheimer's disease as copper deficiency. Med. Hypotheses 70, 802-807, https://doi.org/10.1016/j. mehy.2007.04.051

Kumar V., Kalita J., Misra U.K., Bora H.K. 2015. A study of dose response and organ susceptibility of copper toxicity in a rat model. J. Trace Elem. Med. Biol. 29, 269-274, https://doi. org/10.1016/j.jtemb.2014.06.004

Lee I.-C., Ko J.-W., Park S.-H., Shin N.-R., Shin I.-S., Moon C., Kim J.H., Kim H.-C., Kim J.-C., 2016. Comparative toxicity and biodistribution assessments in rats following subchronic oral exposure to copper nanoparticles and microparticles. Part. Fibre Toxicol. 13, 56, https://doi.org/10.1186/s12989-0160169-x

Lei R., Wu C., Yang B., Ma H., Shi C., Wang Q., Wang Q., Yuan Y., Liao M., 2008. Integrated metabolomic analysis of the nanosized copper particle-induced hepatotoxicity and nephrotoxicity in rats: A rapid in vivo screening method for nanotoxicity. Toxicol. Appl. Pharmacol. 232, 292-301, https://doi. org/10.1016/j.taap.2008.06.026

Liao M.Y., Liu H.G., 2012. Gene expression profiling of nephrotoxicity from copper nanoparticles in rats after repeated oral administration. Environ. Toxicol. Pharmacol. 34, 67-80, https://doi. org/10.1016/j.etap.2011.05.014

Majewski M., Ognik K., Zdunczyk P., Juskiewicz J., 2017. Effect of dietary copper nanoparticles versus one copper (II) salt: analysis of vasoreactivity in a rat model. Pharmacol. Rep. 69, 1282-1288, https://doi.org/10.1016/j.pharep.2017.06.001 
Manohar S., Selvakumaran R., 2012. Estimation of serum immunoglobulin $\mathrm{E}(\mathrm{lgE})$ level in allergic asthma and allergic rhinitis patients before and after treatment. Eur. J. Exp. Bio. 2, 2199-2205

Matak P., Zumerle S., Mastrogiannaki M. et al., 2013. Copper deficiency leads to anemia, duodenal hypoxia, upregulation of HIF-2 $\alpha$ and altered expression of iron absorption genes in mice. PLoS ONE 8, e59538, https://doi.org/10.1371/journal. pone. 0059538

Megahed M.A., Hassanin K.M.A., Youssef I.M.I., Elfghi A.B.A., Amin K.A., 2014. Alterations in plasma lipids, glutathione and homocysteine in relation to dietary copper in rats. J. Invest. Biochem. 1, 21-25, https://doi.org/10.5455/ jib.20130716075753

Ognik K., Stępniowska A., Cholewińska E., Kozłowski K., 2016. The effect of administration of copper nanoparticles to chickens in drinking water on estimated intestinal absorption of iron, zinc, and calcium. Poult. Sci. 95, 2045-2051, https://doi. org/10.3382/ps/pew200

Opazo C.M., Greenough M.A., Bush A.I., 2014. Copper: from neurotransmission to neuroproteostasis. Front. Aging Neurosci. 6, 143, https://doi.org/10.3389/fnagi.2014.00143

Ozkul H., Kirkpinar F., Mert S., Unlu B., 2011. Effects of high levels of dietary copper sulfate and copper proteinate on growth performance, retention for copper and zinc of rats. J. Anim. Vet. Adv. 10, 1373-1377, https://doi.org/10.3923/ javaa.2011.1373.1377

Pyatskowit J.W., Prohaska J.R., 2008. Copper deficient rats and mice both develop anemia but only rats have lower plasma and brain iron levels. Comp. Biochem. Physiol. C-Toxicol. Pharmacol. 147, 316-323, https://doi.org/10.1016/j. cbpc.2007.11.008

Reeves P.G., 1997. Components of the AIN-93 diets as improvements in the AIN-76A diet. J. Nutr. 127, 838S-8341S, https://doi. org/10.1093/jn/127.5.838S

Roche M., Rondeau P., Singh N.R., Tarnus E., Bourdon E., 2008. The antioxidant properties of serum albumin. FEBS Lett. 582, 1783-1787, https://doi.org/10.1016/j.febslet.2008.04.057

Scheiber I.F., Mercer J.F.B., Dringen R., 2014. Metabolism and functions of copper in brain. Prog. Neurobiol. 116, 33-57, https:// doi.org/10.1016/j.pneurobio.2014.01.002
Seol J.-K., Jeong J.-H., Nam S.-Y., Yun J.-W., Kim J.-S., Lee B.-J., 2015. Comparison of the bioavailability of nano- and micro-sized copper oxide particles in copper-deficient mice. J. Prev. Vet. Med., 39, 3-14, https://doi.org/10.13041/ jpvm.2015.39.1.3

Shukla S., Bhatnagar P., Banerjee P., Flora S.J.S., 2015. Effect of sub chronic exposure of copper on some hematological and hepatological parameters in male Wistar rats. IIS Univ. J. Sci. Technol. 4, 41-46

Song M., Schuschke D.A., Zhou Z., Chen T., Pierce W.M. Jr., Wang R., Johnson W.T., McClain C.J., 2012. High fructose feeding induces copper deficiency in Sprague-Dawley rats: a novel mechanism for obesity related fatty liver. J. Hepatol. 56, 433-440, https://doi.org/10.1016/j.jhep.2011.05.030

Smith A.D., Botero S., Levander O.A., 2008. Copper deficiency increases the virulence of amyocarditic and myocarditic strains of coxsackievirus B3 in mice. J. Nutr. 138, 849-855, https:// doi.org/10.1093/jn/138.5.849

Tanaka T., Narazaki M., Kishimoto T., 2014. IL-6 in inflammation, immunity, and disease. Cold Spring Harb. Perspect. Biol. 6, a016295, https://doi.org/10.1101/cshperspect.a016295

Tomaszewska E., Dobrowolski P., Kwiecień M., Burmańczuk N., Badzian B., Szymańczyk S., Kurlak P., 2014. Alterations of liver histomorphology in relation to copper supplementation in inorganic and organic form in growing rats. Bull. Vet. Inst. Pulawy 58, 479-486, https://doi.org/10.2478/bvip-2014-0073

Vulpe C.D., Kuo Y.-M., Murphy T.L., Cowley L., Askwith C., Libina N., Gitschier J., Anderson G.J., 1999. Hephaestin, a ceruloplasmin homologue implicated in intestinal iron transport, is defective in the sla mouse. Nat. Genet. 21, 195-199, https://doi. org/10.1038/5979

Wazir S.M., Ghobrial I., 2017. Copper deficiency, a new triad: anemia, leucopenia, and myeloneuropathy. J. Community Hosp. Intern. Med. Perspect. 7, 265-268, https://doi.org/10.1080/200 09666.2017.1351289

Wöhrl S., Hemmer W., Focke M., Götz M., Jarisch R., 2001. Copper allergy revisited. J. Am. Acad. Dermatol. 45, 863-870, https:/l doi.org/10.1067/mjd.2001.117729 